\title{
Energy Efficiency Pilot Projects in Jaipur: Testing the Energy Conservation Building Code
}

M Evans

J Mathur

$\mathrm{S} Y u$

March 2014

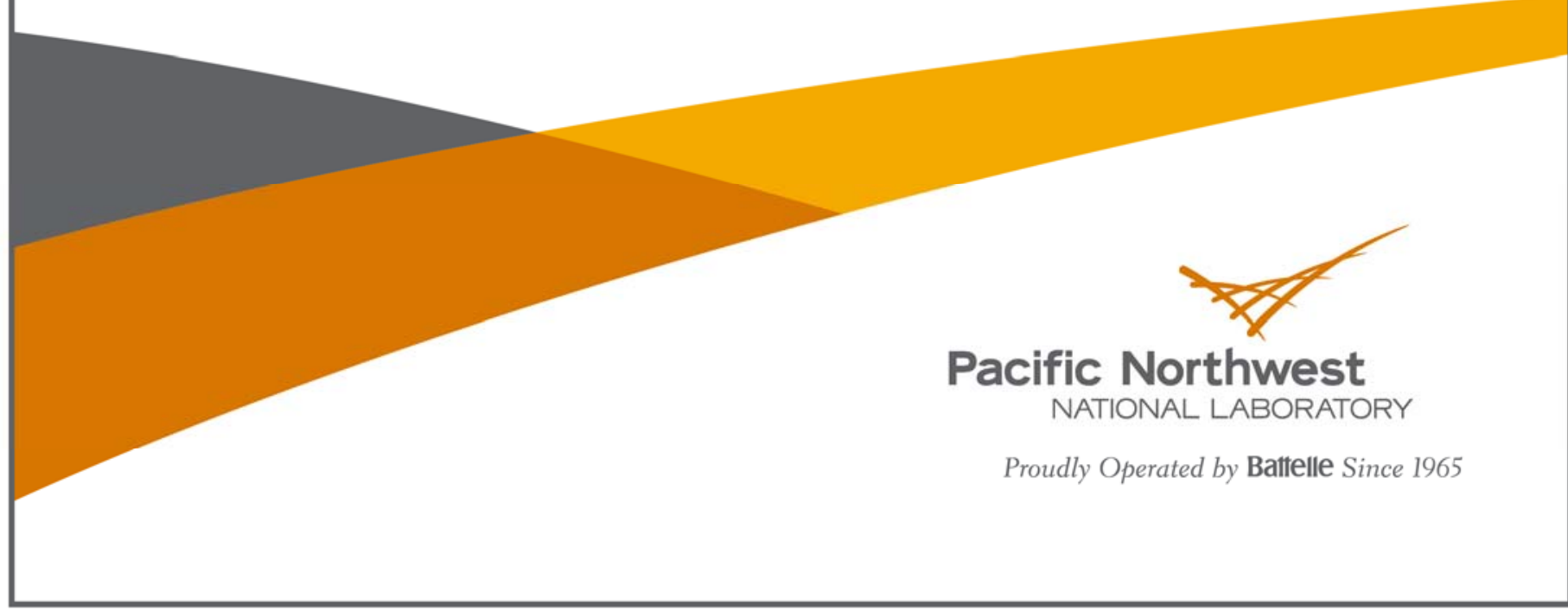




\title{
DISCLAIMER
}

This report was prepared as an account of work sponsored by an agency of the United States Government. Neither the United States Government nor any agency thereof, nor Battelle Memorial Institute, nor any of their employees, makes any warranty, express or implied, or assumes any legal liability or responsibility for the accuracy, completeness, or usefulness of any information, apparatus, product, or process disclosed, or represents that its use would not infringe privately owned rights. Reference herein to any specific commercial product, process, or service by trade name, trademark, manufacturer, or otherwise does not necessarily constitute or imply its endorsement, recommendation, or favoring by the United States Government or any agency thereof, or Battelle Memorial Institute. The views and opinions of authors expressed herein do not necessarily state or reflect those of the United States Government or any agency thereof.

\author{
PACIFIC NORTHWEST NATIONAL LABORATORY \\ operated by \\ BATTELLE \\ for the \\ UNITED STATES DEPARTMENT OF ENERGY \\ under Contract DE-AC05-76RL01830
}

Printed in the United States of America

Available to DOE and DOE contractors from the Office of Scientific and Technical Information,

P.O. Box 62, Oak Ridge, TN 37831-0062;

ph: (865) 576-8401

fax: $(865) 576-5728$

email: reports@adonis.osti.gov

Available to the public from the National Technical Information Service

5301 Shawnee Rd., Alexandria, VA 22312 ph: (800) 553-NTIS (6847)

email: orders@ntis.gov <http://www.ntis.gov/about/form.aspx>

Online ordering: http://www.ntis.gov

This document was printed on recycled paper. 


\title{
Energy Efficiency Pilot Projects in Jaipur: Testing the Energy Conservation Building Code
}

\author{
M Evans \\ J Mathur ${ }^{1}$ \\ $\mathrm{S} \mathrm{Yu}$
}

March 2014

Prepared for

the U.S. Department of Energy

under Contract DE-AC05-76RL01830

Pacific Northwest National Laboratory

Richland, Washington 99352

\footnotetext{
${ }^{1}$ Jyotirmay Mathur is affiliated with the Malaviya National Institute of Technology (MNIT).
} 



\section{Energy Efficiency Pilot Projects in Jaipur: Testing the Energy Conservation Building Code}

The Malaviya National Institute of Technology (MNIT) in Jaipur, India is constructing two new buildings on its campus that allow it to test implementation of the Energy Conservation Building Code (ECBC), which Rajasthan made mandatory in 2011. PNNL has been working with MNIT to document progress on ECBC implementation in these buildings. Table 1 below shows highlights of the buildings:

\begin{tabular}{|c|c|c|}
\hline Building/Characteristic & Design Centre & $\begin{array}{l}\text { Lecture and Theatre } \\
\text { Complex }\end{array}$ \\
\hline Project description & $\begin{array}{l}\text { Additional two floors to } \\
\text { expand an existing building; } \\
\text { the building will provide } \\
\text { training space for ECBC and } \\
\text { green building stakeholders }\end{array}$ & $\begin{array}{l}\text { A large, new building } \\
\text { complex with multiple lecture } \\
\text { halls, classrooms and } \\
\text { multipurpose meeting space. } \\
\text { The core building is } 5 \text { stories, } \\
\text { linked to a } \\
\text { theatre/multipurpose complex. }\end{array}$ \\
\hline Anticipated savings & $\begin{array}{l}\text { Approximately } 20 \% \text { because } \\
\text { of ECBC measures, plus an } \\
\text { additional } 20 \% \text { above code } \\
\text { because of additional } \\
\text { measures and solar PV }\end{array}$ & $\begin{array}{l}\text { Not yet simulated, but } \\
\text { estimate } 20+\%\end{array}$ \\
\hline $\begin{array}{l}\text { Technologies deployed or } \\
\text { planned }\end{array}$ & $\begin{array}{l}\text { Envelope } \\
\text {-Roof insulation (Owens } \\
\text { Corning XPS and some } \\
\text { fiberglass) } \\
\text {-Wall insulation (BASF XPS, } \\
\text { sandwiched between the wall } \\
\text { layers) } \\
\text {-Double-glazed windows with } \\
\text { St. Gobain glass and Fenesta } \\
\text { frames } \\
\text {-Vertical fence shading design } \\
\text { HVAC and PV } \\
\text {-Daikin VRV heat pump air } \\
\text { conditioners } \\
\text {-DRI heat recovery (Dessicant } \\
\text { Rotors International) } \\
\text {-Fiberglass duct insulation } \\
\text {-150 kW rooftop solar PV } \\
\text { Lighting } \\
\text {-LED lighting (not yet }\end{array}$ & $\begin{array}{l}\text { Envelope } \\
\text {-Building oriented for low } \\
\text { heat gain } \\
\text {-Windows face shaded spaces; } \\
\text { few windows on south facing } \\
\text { wall } \\
\text {-Shading } \\
\text {-XPS insulation in roof and } \\
\text { walls (planned, will procure in } \\
\text { April-May 2014) } \\
\text {-Double-glazed windows } \\
\text { (planned, procure in April- } \\
\text { May) } \\
\text {-Insulation sandwiched in wall } \\
\text { layers (primarily for } \\
\text { earthquake resistance, already } \\
\text { installed) } \\
\text { HVAC and PV } \\
\text {-Natural ventilation in } \\
\text { corridors and other common } \\
\text { spaces } \\
\text {-HVAC (plan variable air }\end{array}$ \\
\hline
\end{tabular}




\begin{tabular}{|c|c|c|}
\hline & $\begin{array}{l}\text { procured) } \\
\text { Controls } \\
\text {-Building Management } \\
\text { System (not yet procured, } \\
\text { options may include } \\
\text { Honeywell, Schneider or } \\
\text { Lutron) }\end{array}$ & $\begin{array}{l}\text { volume AC with heat recovery } \\
\text { and controls, will procure in } \\
\text { March-April; UT has helped } \\
\text { with design) } \\
\text {-Solar PV on roof (not yet } \\
\text { defined) } \\
\text { Lighting } \\
\text {-Not yet defined, likely LED } \\
\text {-Natural day lighting through } \\
\text { shaded spaces } \\
\text { Controls } \\
\text {-Building Management } \\
\text { System integrated for HVAC } \\
\text { and lighting (UT has also } \\
\text { helped with design) }\end{array}$ \\
\hline Status of pilot & $\begin{array}{l}\text { Building should be complete } \\
\text { by April 2014. Lighting is the } \\
\text { major remaining item for } \\
\text { ECBC compliance to be } \\
\text { procured. Once the building is } \\
\text { finished and occupied, MNIT } \\
\text { will conduct final, as-built } \\
\text { simulation of the building to } \\
\text { estimate savings. MNIT will } \\
\text { also monitor the building's } \\
\text { energy use to compare it with } \\
\text { the estimates. Typically, it } \\
\text { takes one year of measurement } \\
\text { to present measured results. }\end{array}$ & $\begin{array}{l}\text { Building construction has } \\
\text { begun; completion expected in } \\
\text { approximately } 18 \text { months. } \\
\text { Design incorporates green } \\
\text { building features associated } \\
\text { with the building footprint } \\
\text { (orientation, shading, natural } \\
\text { ventilation and day light). } \\
\text { Once the HVAC is procured, } \\
\text { MNIT will conduct initial } \\
\text { building energy simulation of } \\
\text { the building design to show to } \\
\text { anticipated energy savings. }\end{array}$ \\
\hline
\end{tabular}

\section{Key lessons learned to date:}

- Buildings can save significant energy with ECBC implementation.

- Procurements in public buildings like those on MNIT's campus can be complex. MNIT found that not all the materials and equipment it needed for ECBC compliance were available on the list of approved products for government procurements. The Central Public Works Department maintains this list, which is known as the“Schedule of Rates”. This slowed down the procurement of LED lighting in the Design Centre. It also affected other procurements for ECBC materials, which in some cases lowered the efficiency of the building. MNIT compensated for this by adding $150 \mathrm{~kW}$ of solar PV. The Bureau of Energy Efficiency has since worked with the Central Public Works Department to update the Schedule of Rates. However, public buildings must still show lowest first cost, which is a challenge for many efficiency measures which typically have low life cycle costs, but slightly higher first costs. 
- MNIT conducted significant analysis to build the business case for purchasing materials and equipment that helped with ECBC compliance. This information will be helpful to other public facilities.

- Manufacturers may overstate energy performance of the materials and equipment. MNIT noticed this when they conducted their own simulation of the windows they planned to install. A robust system to test, rate and label products will make ECBC implementation easier.

- MNIT was able to use eQuest, a building energy simulation program, to assess whether the planned design met ECBC requirements. It would be very helpful to have robust, easy-to-use compliance software. This requires improving the functionality of ECOnirman.

- All central government public buildings must now meet ECBC requirements because they must have a green building certification. Public buildings do not need to receive construction or occupancy permits from the local government, but rather, they receive this approval from the central or state public works departments. Strengthening the capacity of these public works departments to implement ECBC in all their buildings will help build momentum to mainstream ECBC implementation.

- Due to the ease of interpreting prescriptive requirements, CPWD and other government organizations prefer the prescriptive method of compliance. MNIT, on the other hand, has preferred the whole building method. Due to this, some requirements in the MNIT pilot buildings were more stringent than ECBC prescriptive values to compensate for other components. This made the procurement process significantly lengthier. One such case has been lighting, in which the lighting power density chosen is much lower than ECBC requirements, thus raising the level of specifications of lighting fixtures and controllers.

The sections below on the Design Centre and the Lecture and Theatre Complex provide photos of the two pilot buildings from February 2014, highlighting energy efficiency and renewable energy measures, and the status of construction. 


\section{The Design Centre, MNIT Campus}

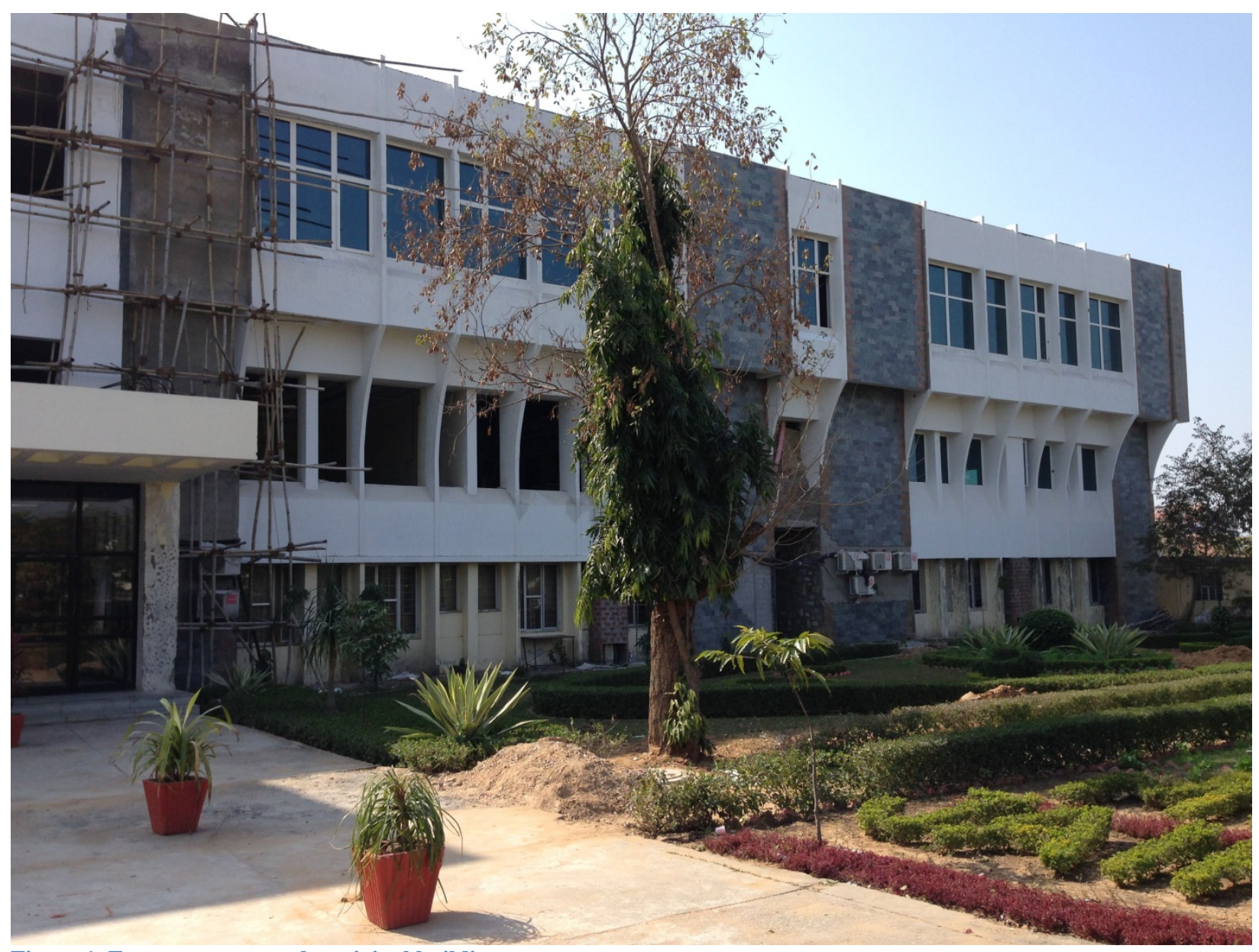

Figure 1. Front entrance to the original building 


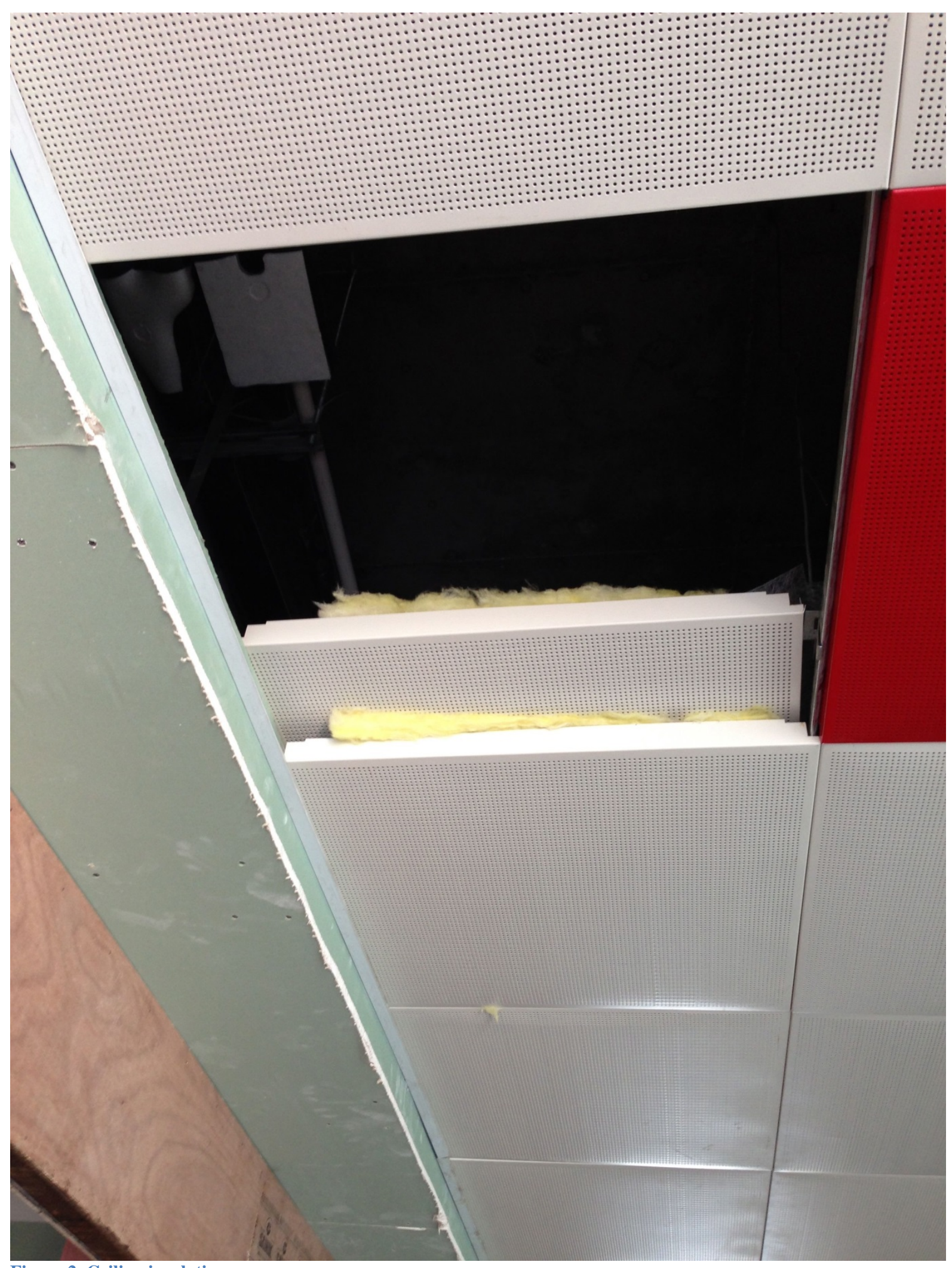

Figure 2. Ceiling insulation 


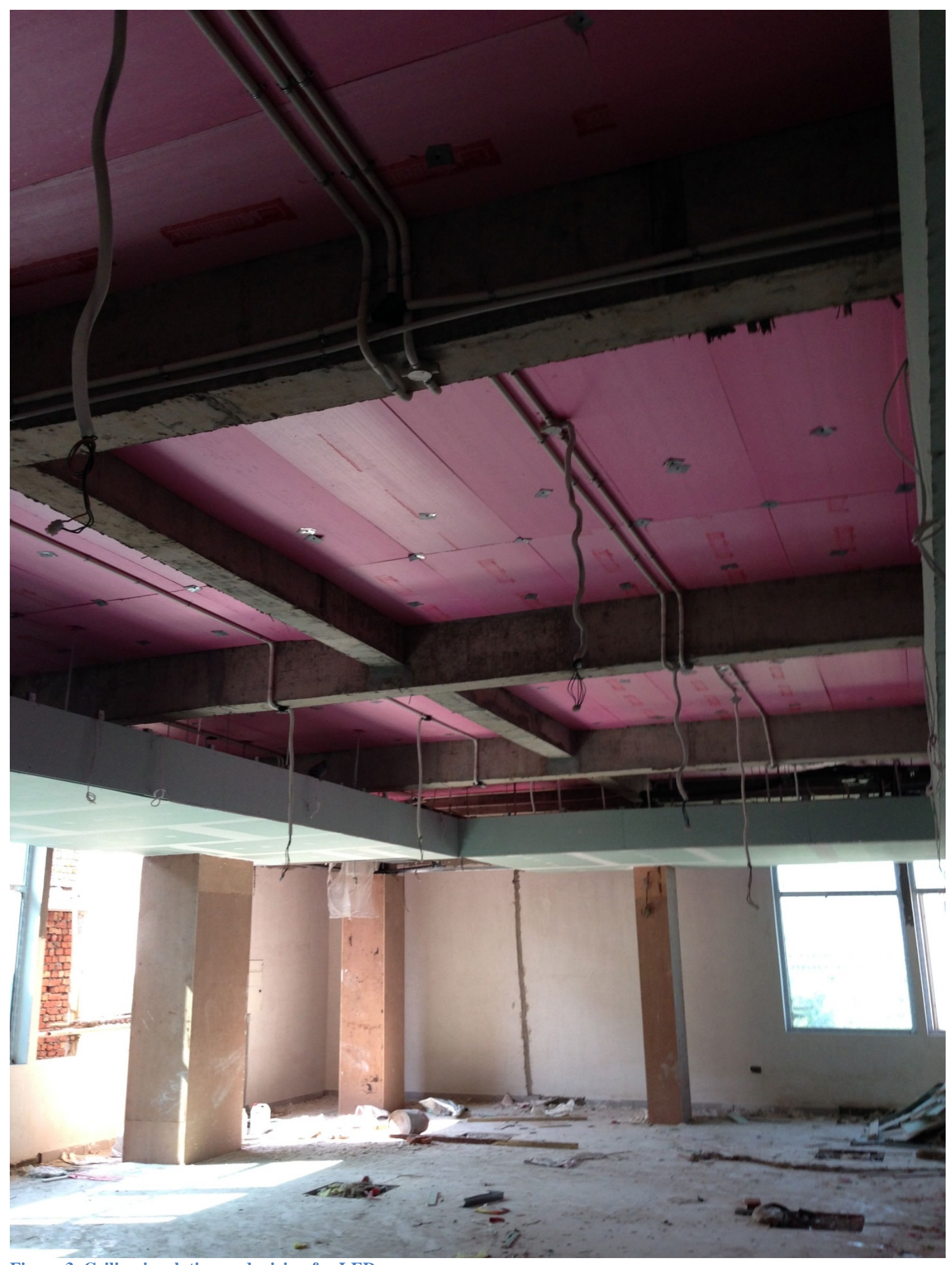

Figure 3. Ceiling insulation and wiring for LEDs 


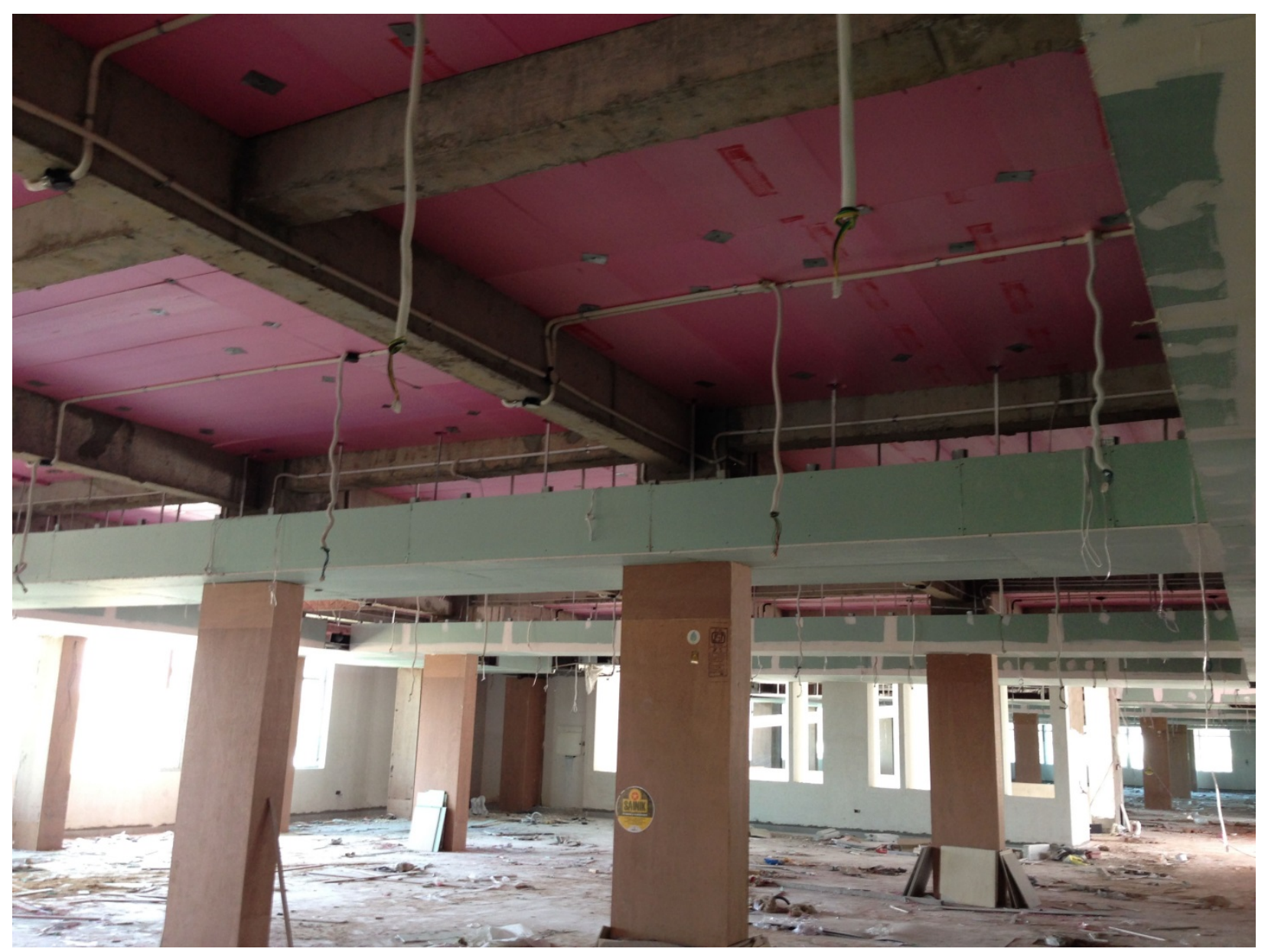

Figure 4. Ceiling insulation, wiring for LEDs and natural day light 


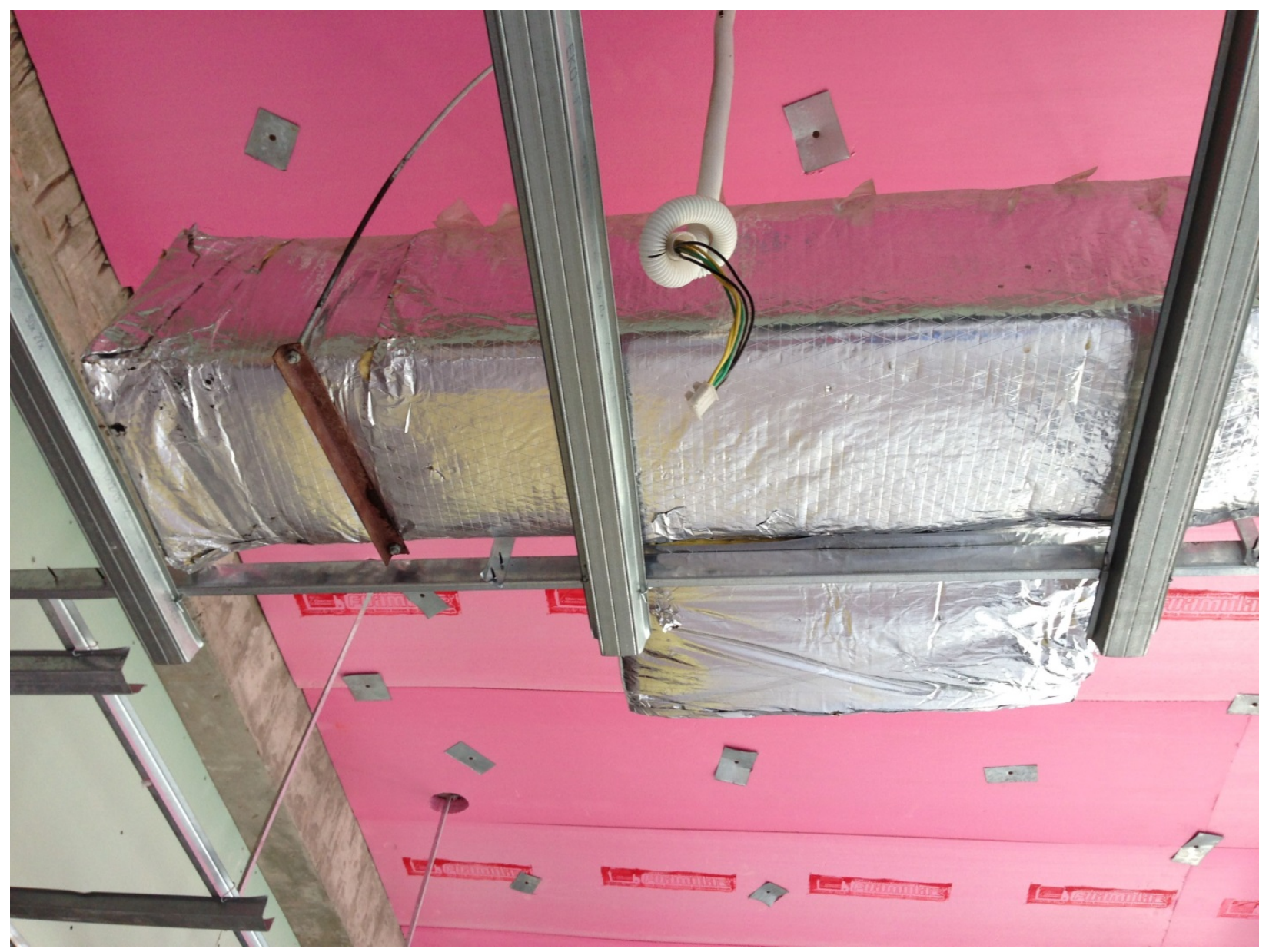

Figure 5. Duct and ceiling insulation 


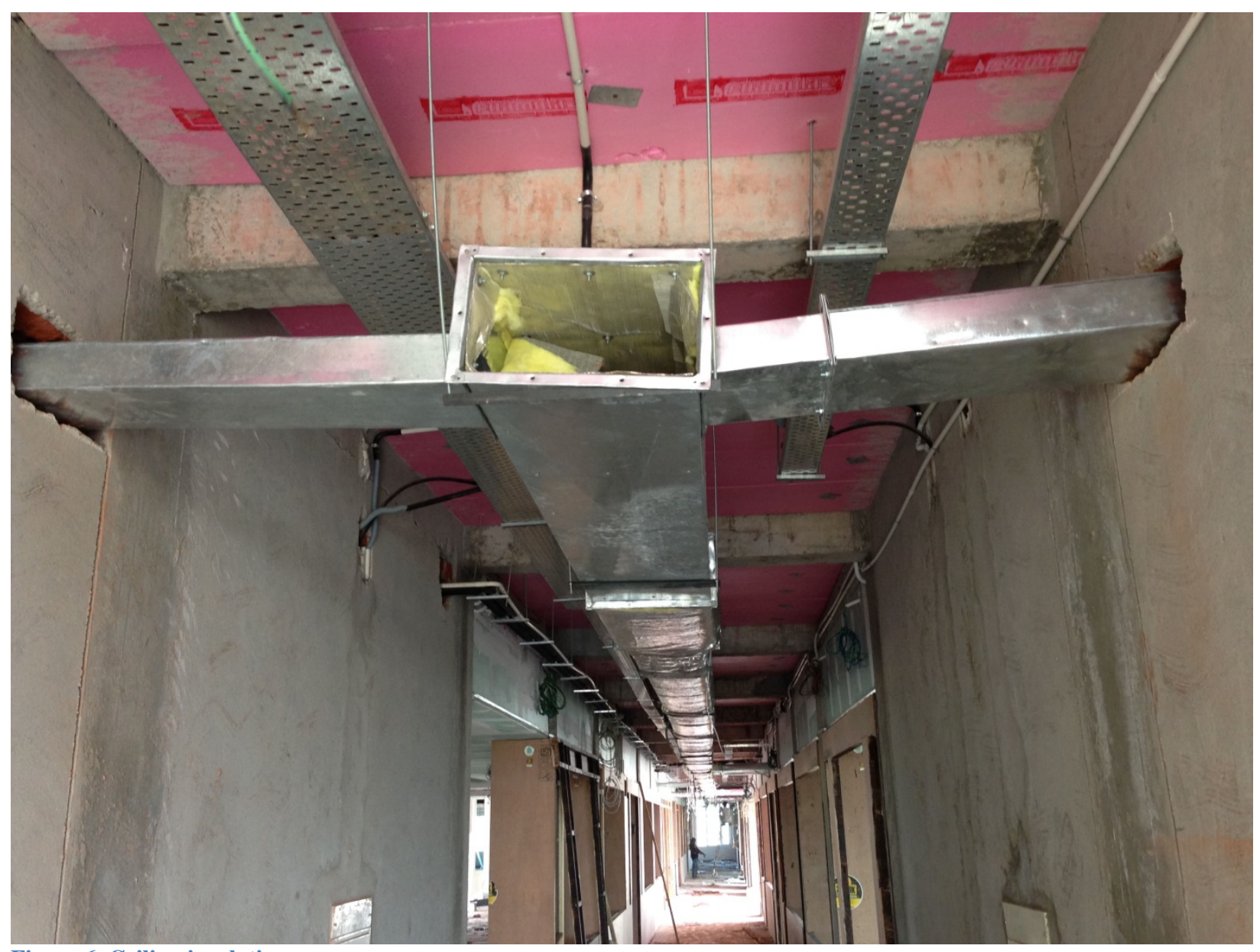

Figure 6. Ceiling insulation 


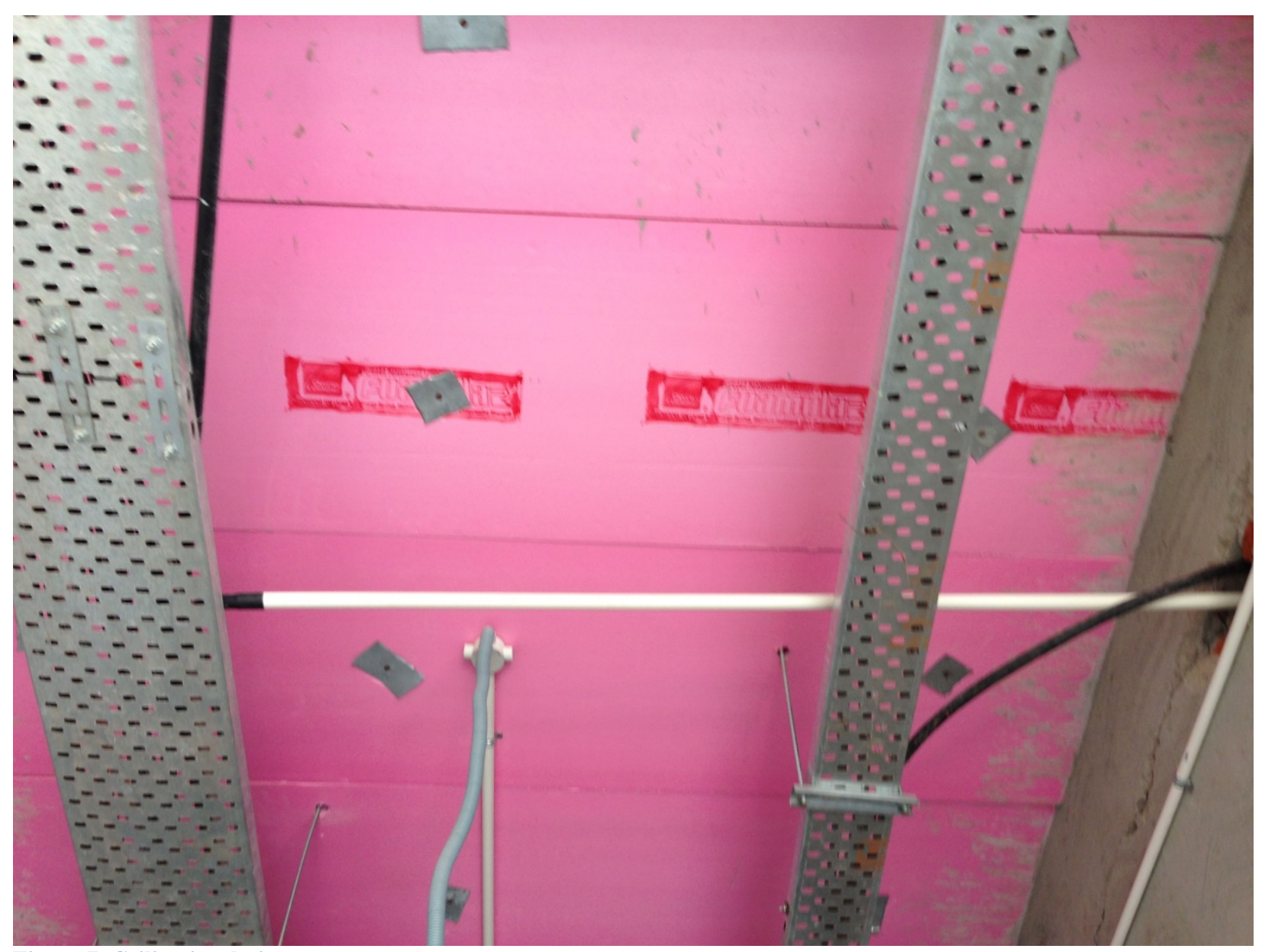

Figure 7. Ceiling insulation 


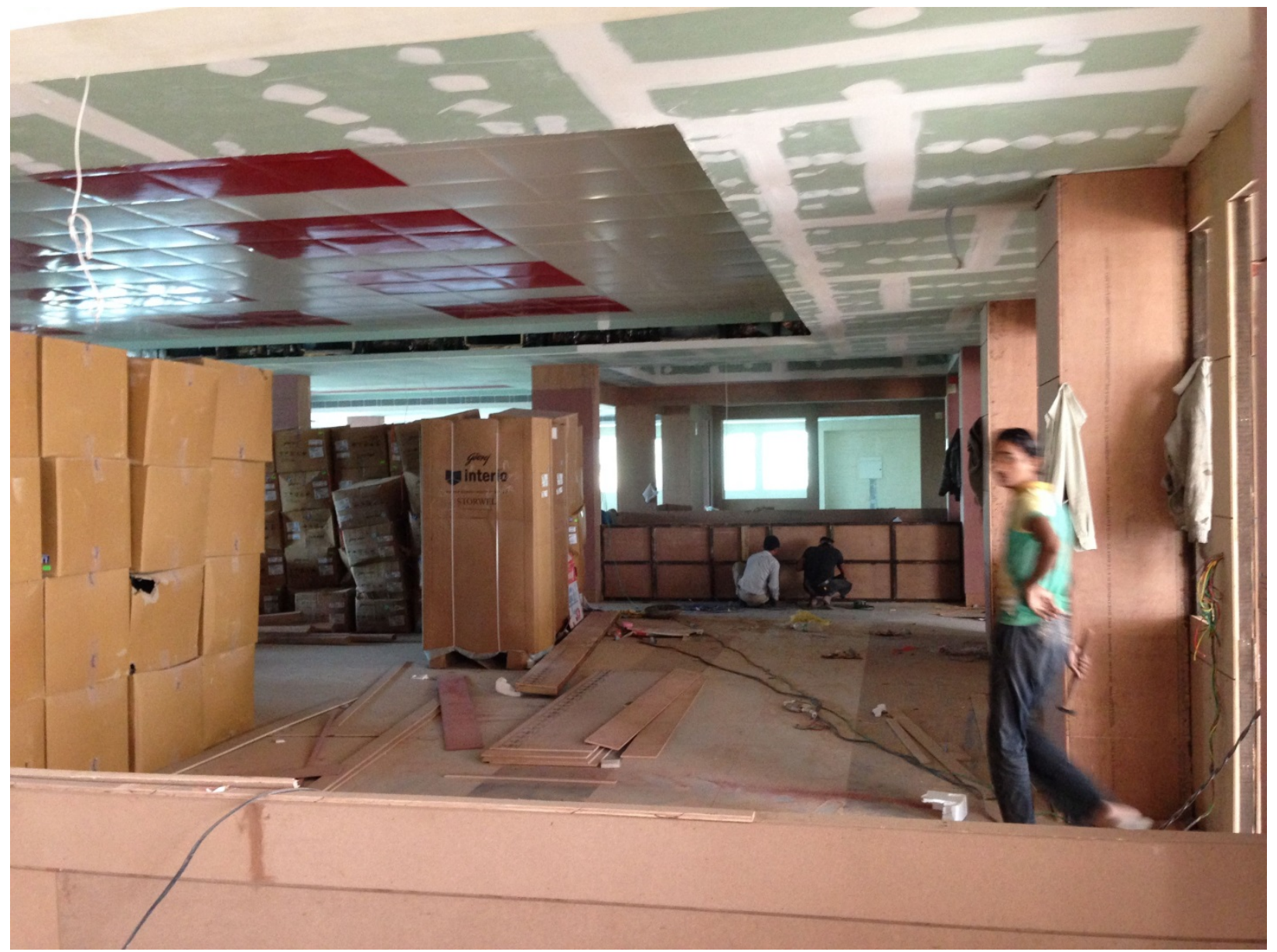

Figure 8. Meeting space 


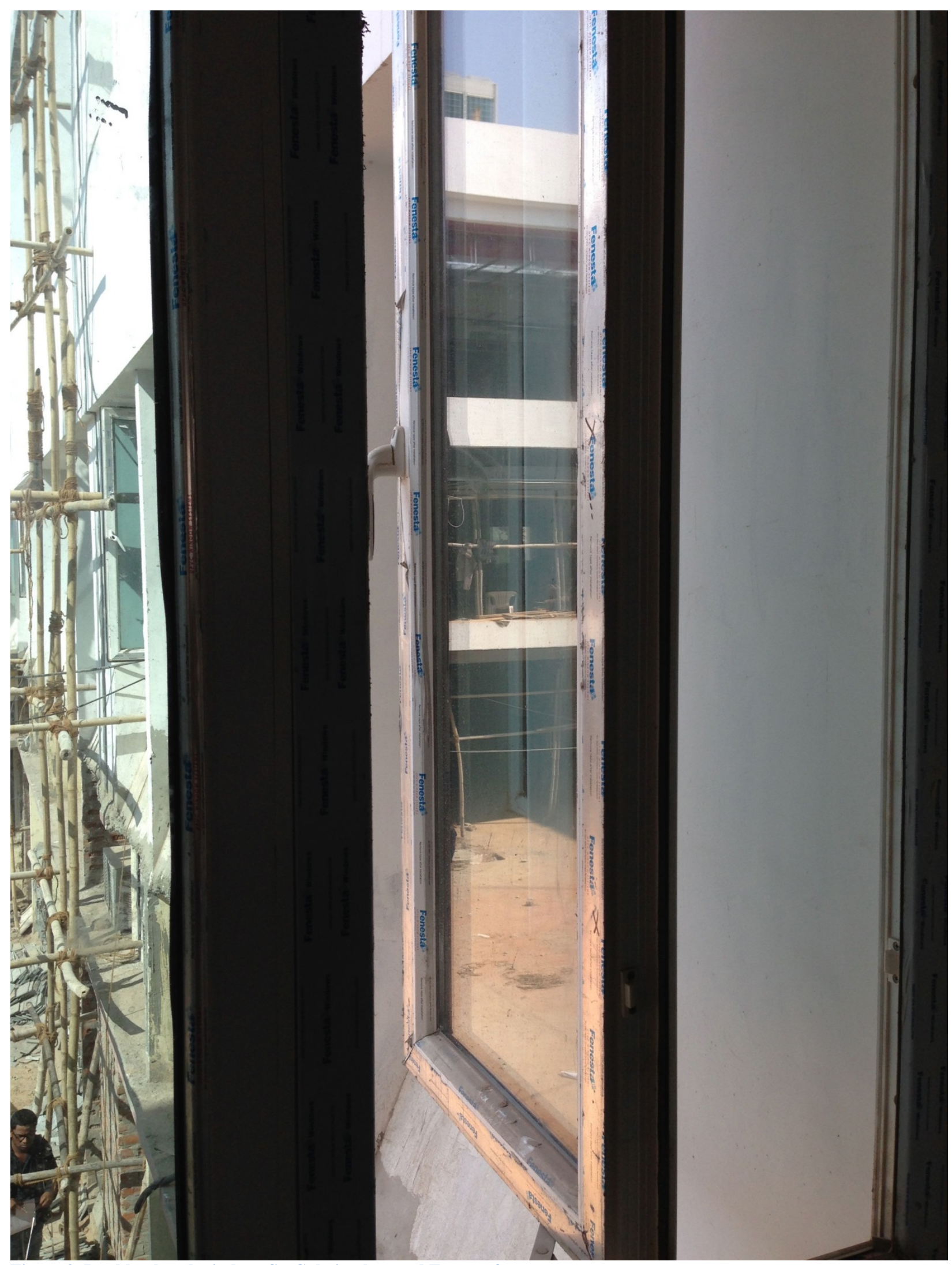

Figure 9. Double-glazed window, St. Gobain glass and Fenesta frame 


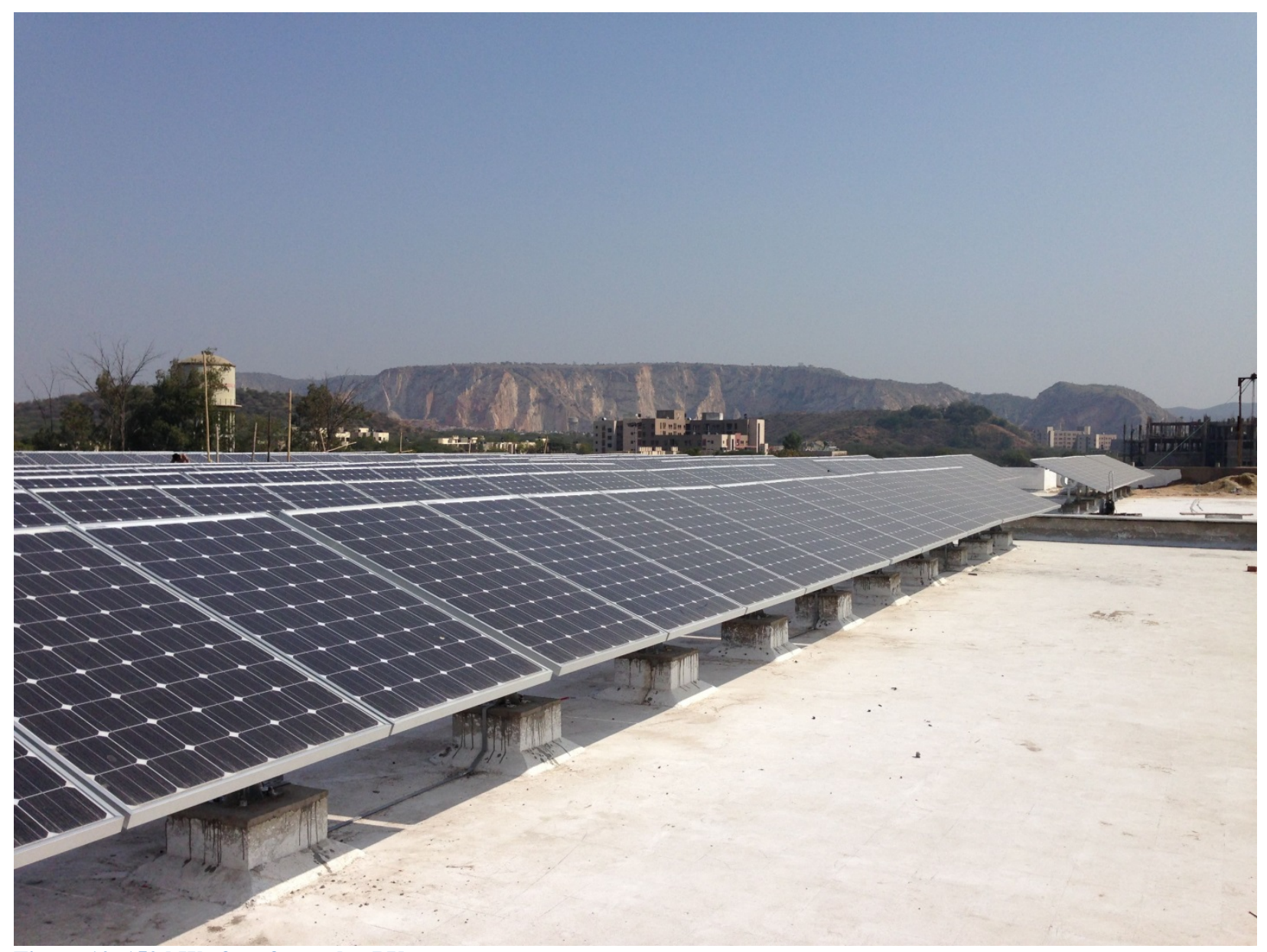

Figure 10. $150 \mathrm{~kW}$ of rooftop solar PV 


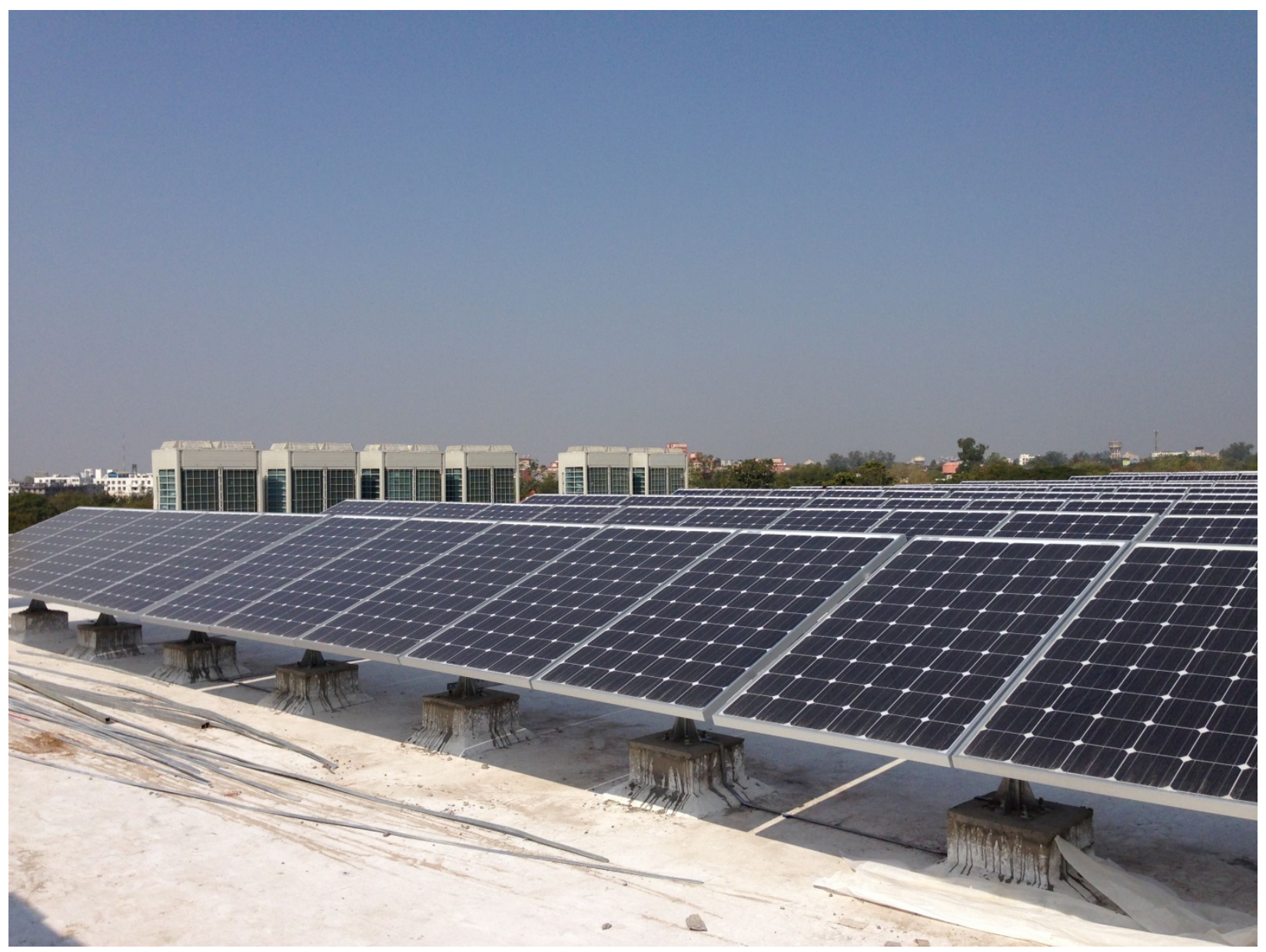

Figure 11. Rooftop PV and VRV air conditioning system 


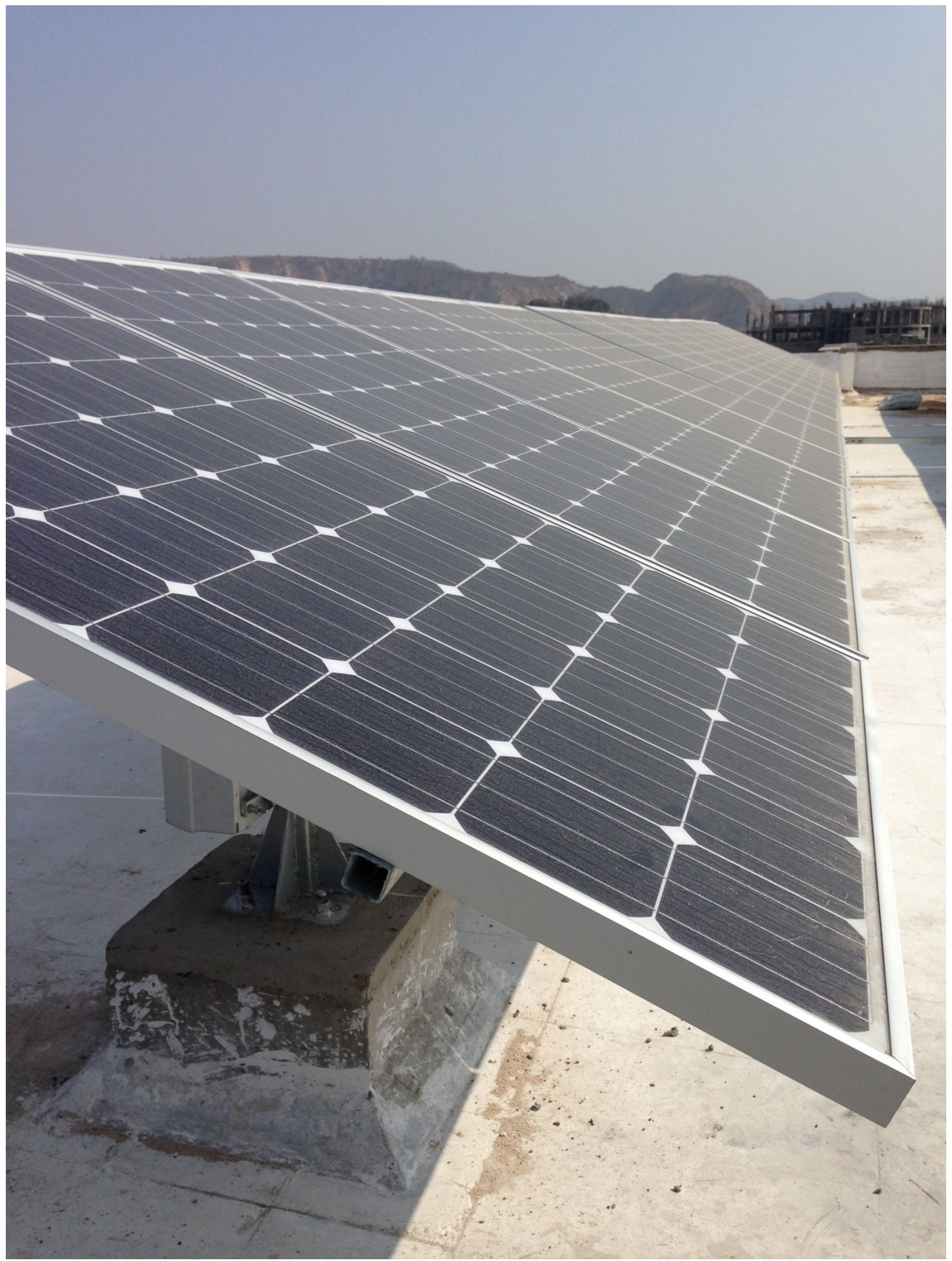

Figure 12. Solar PV 


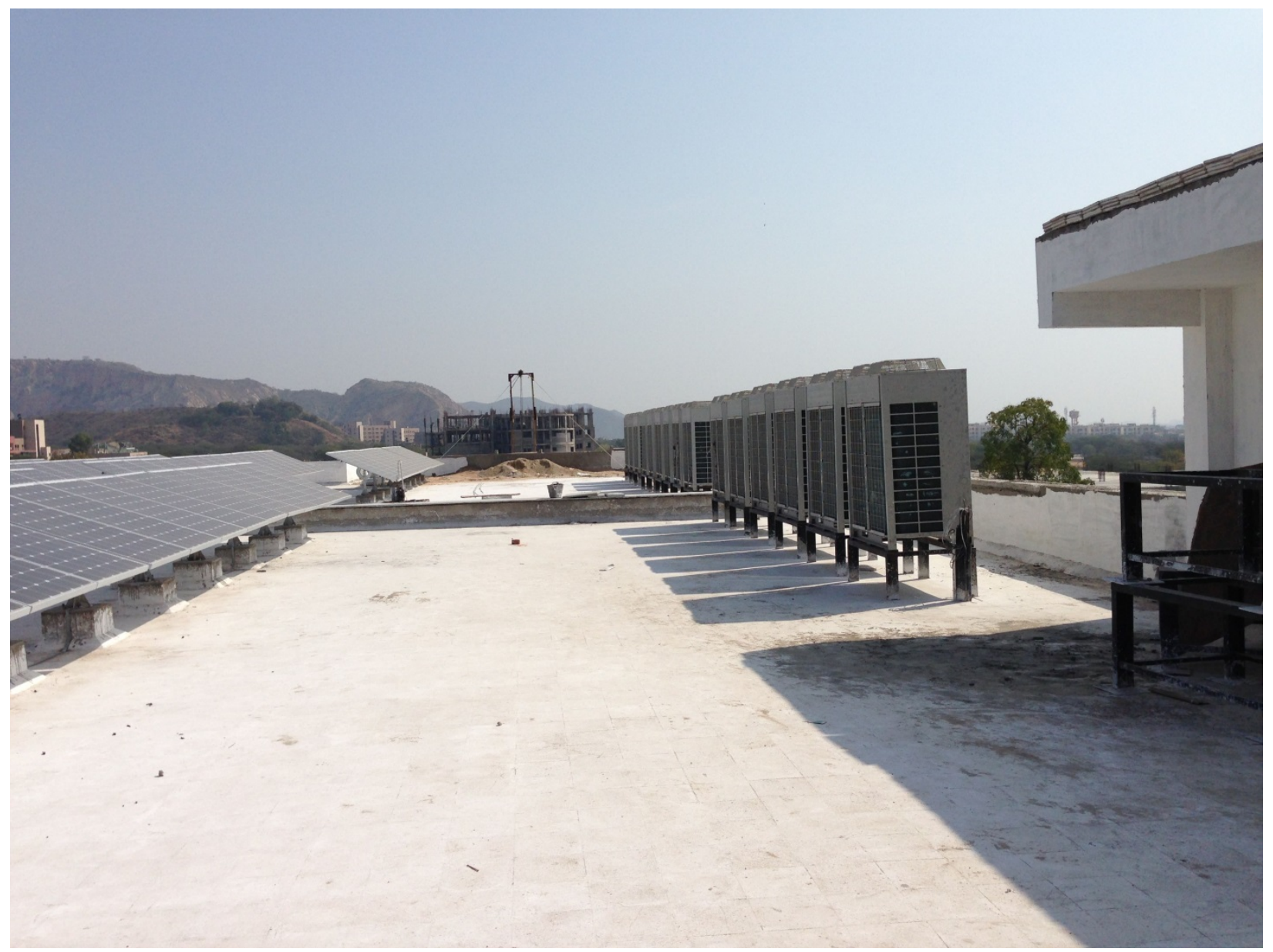

Figure 13. Solar PV and VRV air conditioning units 
The Lecture and Theatre Complex (under construction at MNIT's campus)

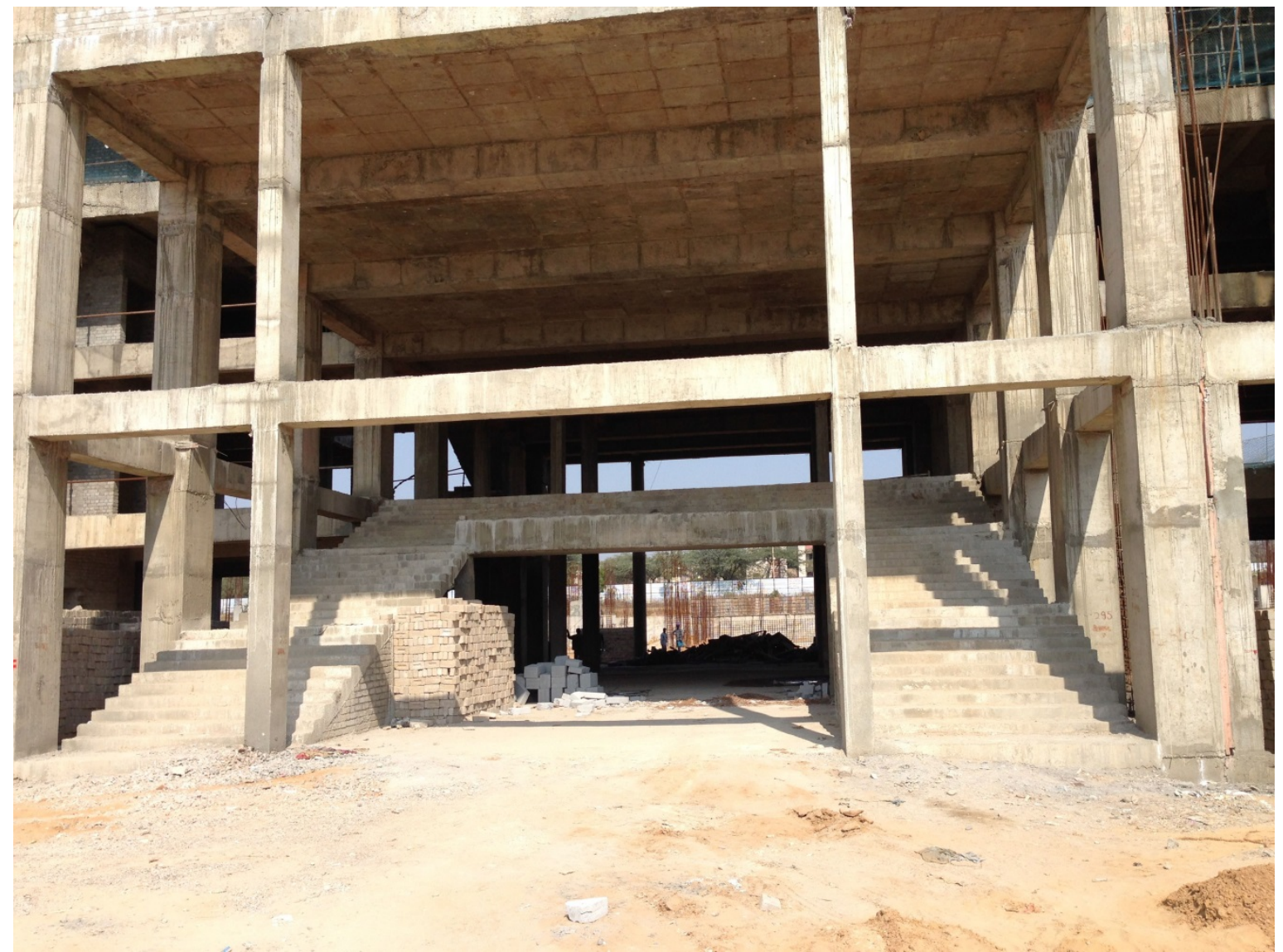

Figure 14. Main entrance. Day lighting, shading and natural ventilation. 


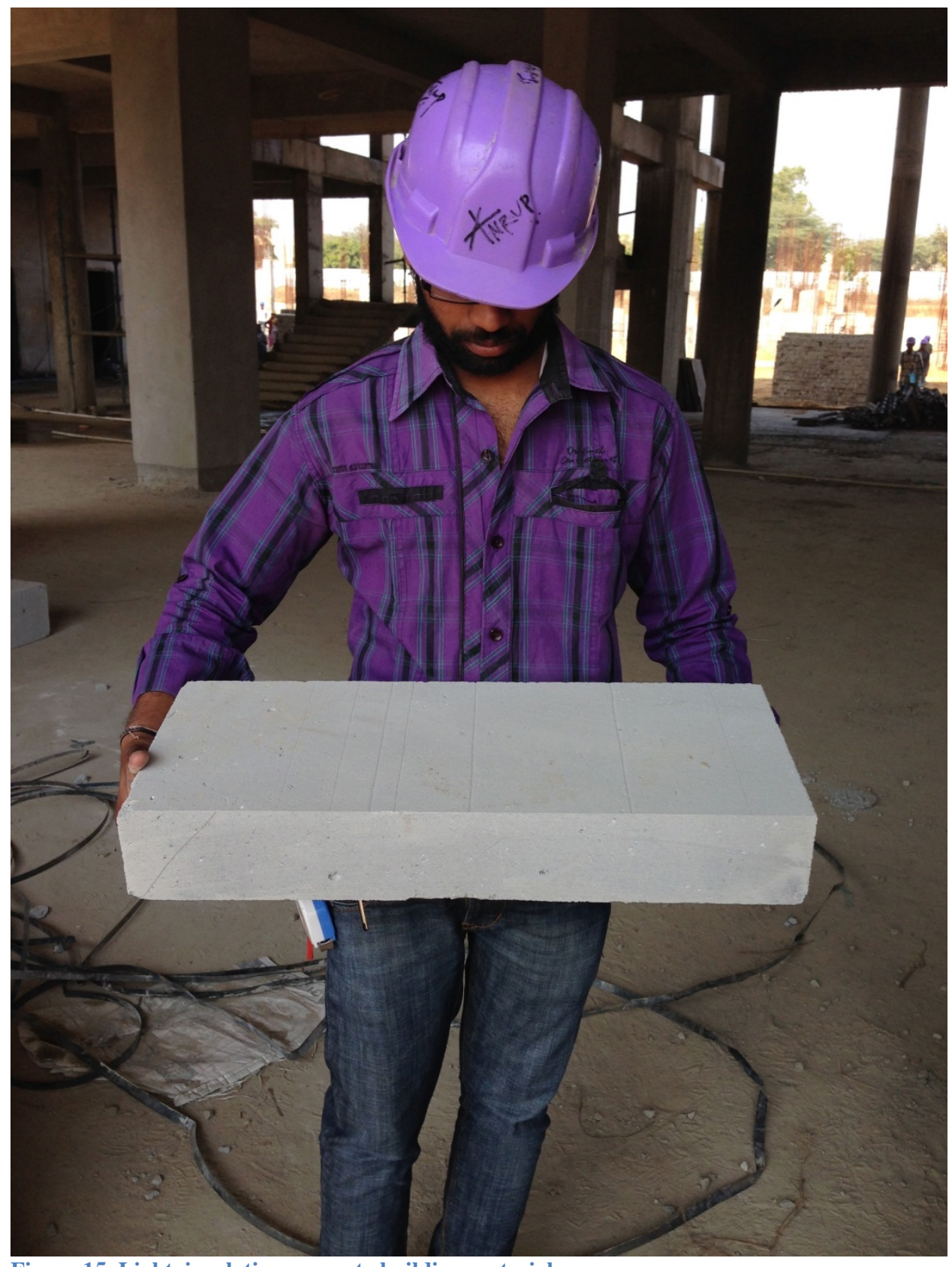

Figure 15. Light, insulating concrete building material 




Figure 16. Foundation of the new complex 


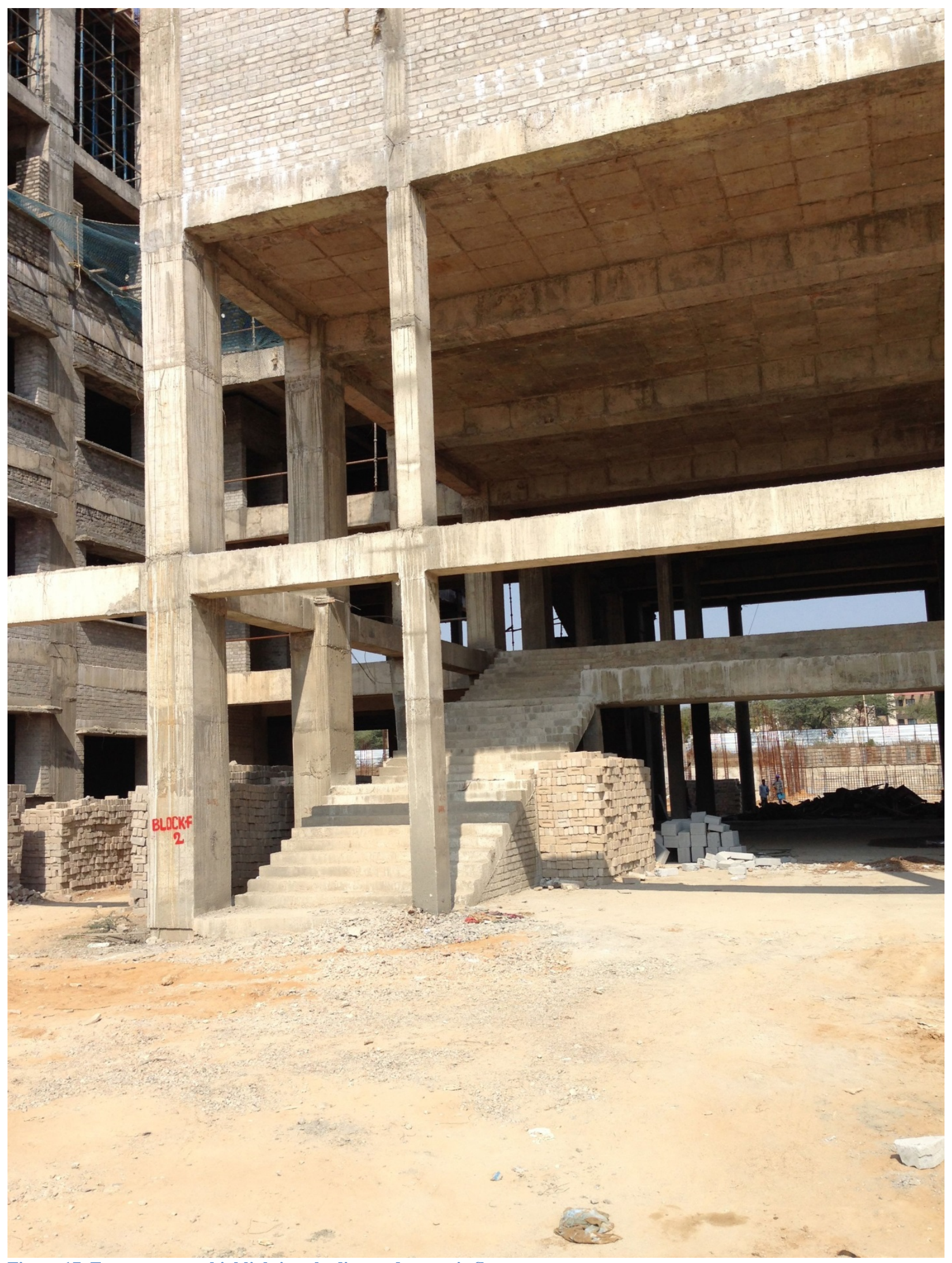

Figure 17. Front entrance highlighting shading and open air flow 


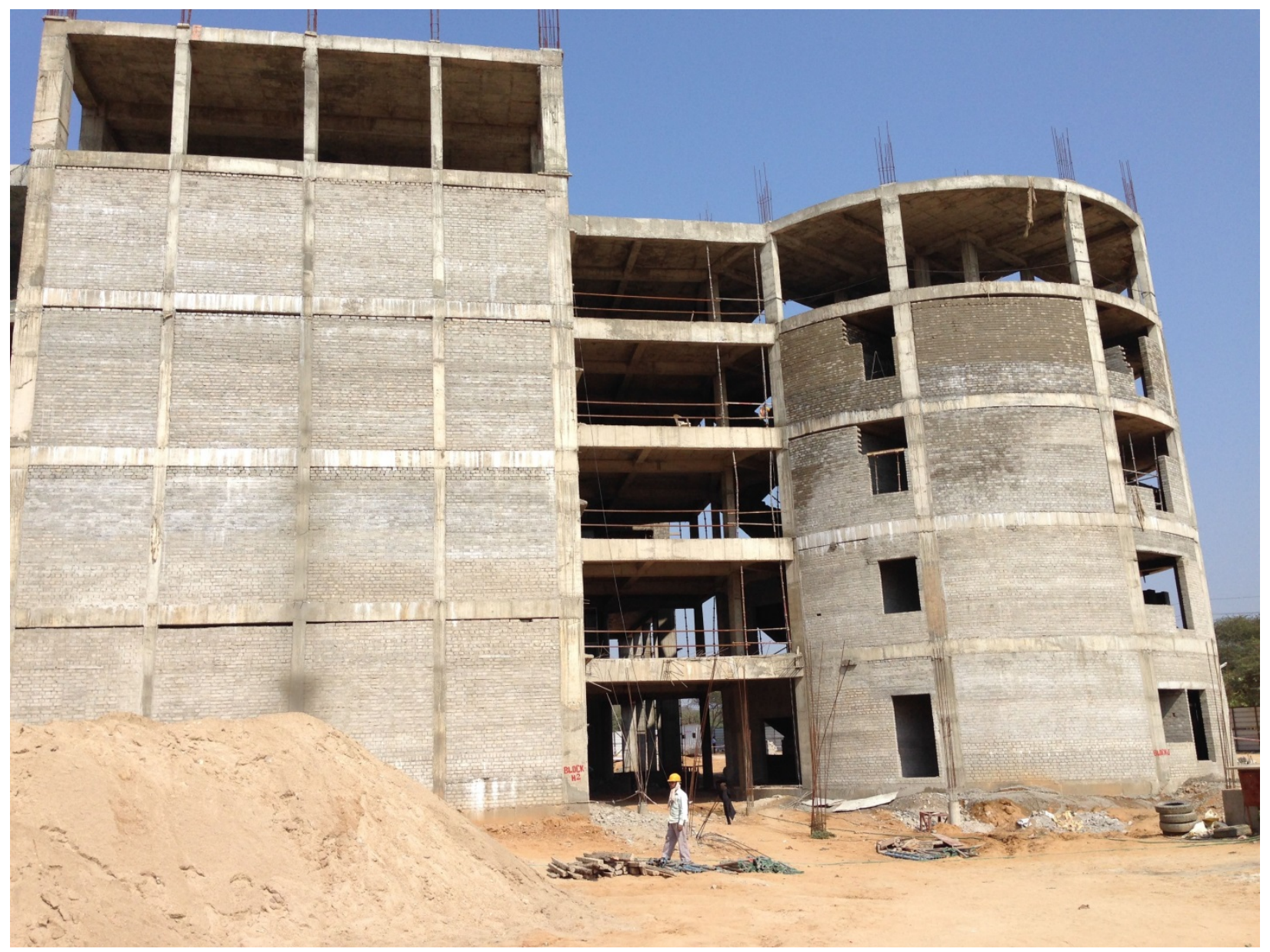

Figure 18. Limited windows on south facing wall, natural ventilation in corridors 


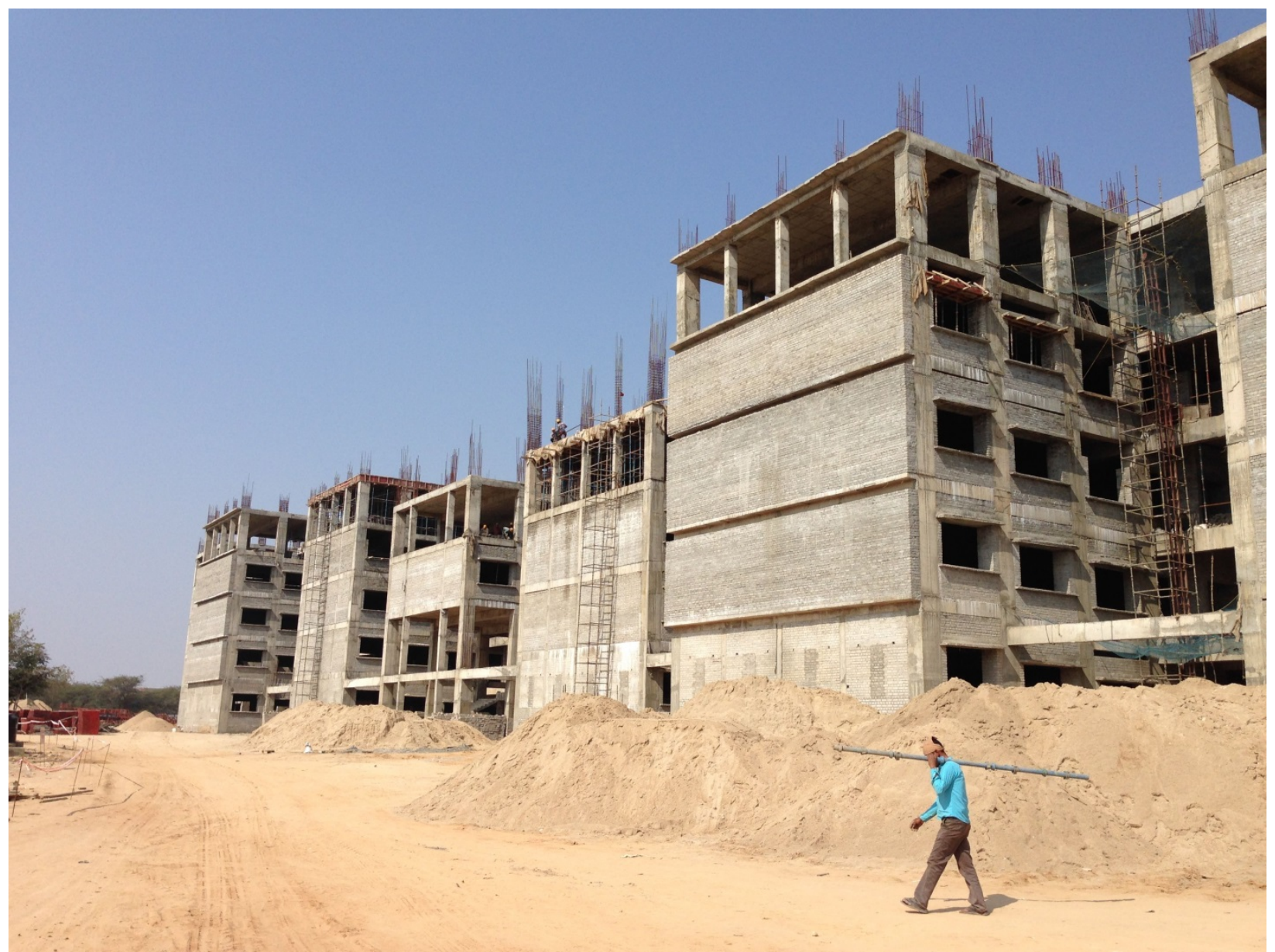

Figure 19. Windows facing shaded spaces 


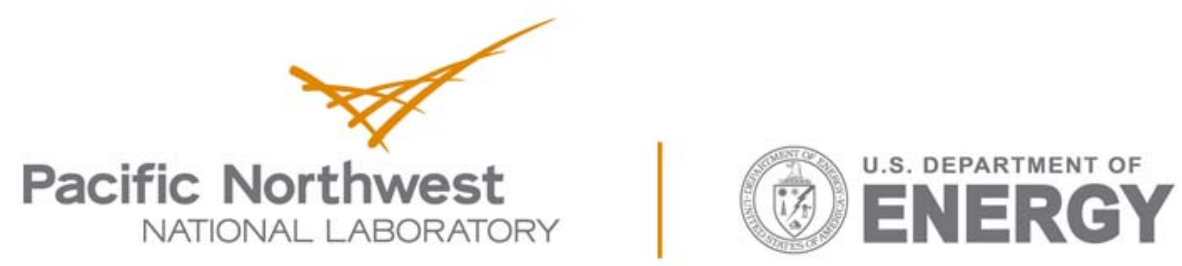

Proudly Operated by Battelle Since 1965

902 Battelle Boulevard

P.O. Box 999

Richland, WA 99352

1-888-375-PNNL (7665)

www.pnnl.gov 